\title{
Multinational Joint Task Force's Fight against Insurgency in the Lake Chad Basin Region
}

\author{
OLUFUNSO KEHINDE ALUFOGE \\ Political Science and International Relations \\ Covenant University \\ Covenant University, Ota, Ogun \\ NIGERIA \\ MOSES METUMARA DURUJI \\ Political Science and International Relations \\ Covenant University \\ Covenant University, Ota, Ogun \\ NIGERIA
}

\begin{abstract}
Describing north east Nigeria without making mention of insurgency would be incomplete, as the resurgence of insurgent groups particularly Jamā'at Ahl as-Sunnah lid-Da'wah wa'l-Jihād commonly refered to as Boko Haram have wreaked havoc in the region for close to 12 years. In response to the activities of insurgent groups, the African Union Peace and Security Council and the authority of the Lake Chad Basin Commission moved to expand the mandate of the MNJT to include counter insurgency. The task force is made up of orcesrom Cameroon, Chad,Niger Nigeria and Benin republic. The task force have been able to make considerable gains against insurgency, however, insurgency still remains a major challenge in the region, which makes necessary an appraisal of the task force in justifying the purpose of its creation. The study reveals major challenges like inadequate technical knowhow, inadequate funding amongst others threatens the operations of the MNJTF. The paper recommends that military response is solely incapable of addressing insurgency, member States need to re-examine counter insurgency policies to be multidimensional.
\end{abstract}

Key-Words: - Insurgency, Counterinsurgency, Lake Chad Basin, Multinational Joint Task Force

Received: June 16, 2020. Revised: November 23, 2020. Accepted: November 25, 2020.

Published: November 26, 2020.

\section{Introduction}

Insurgency has evolved to become a major feature of the international system, particularly in the $21 \mathrm{st}$ century, having being aided by advances in science and technology [1]. Over time, countries have begun to view insurgency as a threat to global peace and stability as against a threat to a country, for this reason governments of countries have often resorted to the establishment of multinational military actions to counter insurgency and other forms of threat to global peace and stability. The 1989 demolition of the Berlin Wall and the end of the Cold-War era led to an increase in the attention paid to Multinational Forces [2], some examples of Multinational forces include; North Atlantic Treaty Organisation (NATO), Economic Community of West African States Monitoring Group (ECOMOG), the European Multinational forces, etc.

Being faced by militancy, political conflict, drug and human trafficking, ethno-religious crisis, transborder crimes and insurgency, governments of Benin, Cameroon, Chad, Niger, and Nigeria established the MNJTF to curb all manners of these illegal activates across the borders of member states particularly the actions of the insurgent group Boko Haram. The insurgent group Boko Haram was not always the violent group that it is today, prior to the 
group's violent nature from 2009, the group was not viewed as a threat to Nigeria or any of her neighbours, Muhammad Yusuf's teachings were usually televised which enabled him garner followers across the region and beyond [3]. Prior to the popularity of Muhammad Yusuf's [4], identifies two driving factors that enabled Yusuf's teachings to appeal to large crowd. The first being that; back in 1999, Borno State Politicians formed a gang of armed youths to take out political opponents, but later in 2002 and 2003, these politicians had little use of the armed youths, making them to neglect the need of the armed gang known as Ecomog [5]. In the quest to find means of livelihood while still armed; some of them turned into the violent and illegal activities, while some others fell into the open arms of Muhammad Yusuf's teachings of Salafism; stating the waywardness of Nigerian politicians and the increasing influence of the Western World. The armed youths and Muhammad Yusuf were a perfect match, he was speaking against the ill practices of politicians, and the armed youths felt used and abandoned by the politicians after the 2003 election. Yusuf's readiness to assist his followers to establish businesses, and also help them get married went round the region which made people to come from across the region to become disciples. The growing followership and nature of teachings began to draw attention to the group; several cases were brought up against him, but none of them were able to lead to Yusuf's arrest. Then in 2009, Yusuf's was extra-judicially killed in police custody with the thought that his death was going to quell the group, however this abuse of power and abuse of human right by the Nigerian police force led to the radicalization of the group under Abubarkar Shekau who moved to transform the group into an insurgent group that makes use of terror to spread its message with aim to achieve a political change of creating a caliphate governed by Islamic law in North East Nigeria.

Since the transformation of the sect into a terrorist group in 2009, the group has adopted such violent tactics like suicide bombing, Car bomb, use of IED and kidnappings. At the early stage, the insecurity threat was considered to be a Nigeria problem, coupled with fact that the Nigerian government under the leadership of Goodluck Jonathan was not willing to have the foreign soldiers on Nigerian soil in the fight against Boko Haram [6].

However in 2012, the transnational nature of the group was reflected when the brother in law of Muhammad Yusuf "Alhaji Babakura Fuggu" told former president Olusegun Obasanjo that about 40\% of the membership are from Cameroon, Chad and
Niger [7], this led to the imperative decision to combine forces to tackle insurgency in the region. The product of this idea was the Multinational Joint Task Force. A combination of forces from Cameroon, Chad, Niger, Nigeria and Benin Republic, the troop is made up 8,500. Despite the creation of this Task Force, insurgency still remains a major character of the Lake Chad Basin Region. Therefore, this paper questions the effectiveness of the MNJTF COIN measure and Challenges to the COIN measures.

\section{Methodology}

Qualitative research is conducted through the collection of data and the analysis thereof is a simultaneous process [8]. This view is also shared by [9], they posits that in qualitative research, data analysis is conducted through the classification of events, persons, items, ideas, things, themes etc. on this premise, analysis of data is this paper was chronologically and categorically organized. Major sources of data for this paper were gotten from reports, government publications, literature survey, conference paper, books among others. Data gathered were then descriptively analyzed.

\section{Literature Review}

\subsection{Insurgency}

The concept of insurgency has been subjected to series of definitions by scholars in social sciences discipline; also the term has been used interchangeably with such terms like terrorism, revolution, and guerilla warfare. Owing to the misuse and diverse use of the word by different scholar, it becomes important to define what insurgency is; a comprehension of it is tantamount to appraising the MNJTF. insurgency is seen to be "a technology of military conflict characterised by small, lightly armed bands practicing guerilla warfare from rural bases [10]" Another definition is put forward by [11], they define insurgency as "a protracted violent struggle by non-State actors to attain their political aims and objectives- often emancipation, greater autonomy, or subversion of existing authorities - against the current political authority (the incumbent)." The definition by [10] unlike the definition put forward by [11] fails to capture the essence of insurgency by characterizing it to be a tactic of small lightly armed band who operate from rural bases practicing guerilla warfare. This definition is inconclusive because it also fails to capture the true purpose of insurgency. The definition overtly recognises insurgency to have a military purpose. The definition put forward by [11] 
does more to capture the true nature of insurgency by defining it as actions by non-State actors who have political aims and objectives. However, this definition does not do well to indicate whether these actions are guerilla warfare or not. A leading scholar on insurgency; O'Neill conceptualizes insurgency is undoubtedly being the most predominant category of organized struggle since the rise of politically organized societies" [12: p-1]. He further posits that insurgency is a general all-encompassing concept that denotes to a struggle between a government and an organized cluster or opponent in which the opponent or sect make use of both violence and political resources to change, reform, or uphold the legitimacy of one or more of four key aspects of politics" [13]. while citing [12], [13] identifies the four keys of politics as being; " (1) the respect and dignity of the State territory, (2) the system of political administration in the country, (3) the people in power and (4) the public and foreign policies of the state.

Over the years, insurgency that is rebellion against the state have taken various forms. They are riot, coup d'etat, guerrilla, revolution and terrorism.

\begin{tabular}{|c|c|c|c|c|c|c|}
\hline $\begin{array}{c}\text { Form of } \\
\text { insurgency }\end{array}$ & $\begin{array}{c}\begin{array}{c}\text { Insurgency } \\
\text { level }\end{array} \\
\end{array}$ & $\begin{array}{l}\text { Number } \\
\text { involved }\end{array}$ & $\begin{array}{l}\text { Struggle } \\
\text { duration }\end{array}$ & Violence & $\begin{array}{l}\text { Threat to } \\
\text { regime }\end{array}$ & Spontaneity \\
\hline Coup d'etat & high & few & short & \begin{tabular}{|l|} 
varies \\
\end{tabular} & great & no \\
\hline $\begin{array}{l}\text { Leninist } \\
\text { Revolution }\end{array}$ & low & many & short ${ }^{2}$ & great & great & no? \\
\hline Guerrilla & Low & medium & long & great & varies & $n 0$ \\
\hline Riot & Low & medium & short & Litrle & small & yes \\
\hline Terrorism & Low & few & long & Litrle ${ }^{3}$ & small & no \\
\hline $\begin{array}{l}\text { Nonviolent } \\
\text { resistance }\end{array}$ & low & many & long & no & varies & no \\
\hline
\end{tabular}

Table 1: Comparison of Forms of Insurgency

The table above shows the different forms of political violence that threatens the regime of a state; it helps to characterize them based on insurgency level, number involved, struggle duration, violence, threat to regime and spontaneity. Although there are a number of strategies to insurgency, this paper focuses on terrorism as a strategy of insurgency. The term terrorism is usually used interchangeably with the term "guerrilla" [14] sees insurgency as a strategy of insurgency, terrorism differs from guerrilla; the tactics associated with these strategies are different. A major difference between them is that guerrilla often tries to establish and maintain physical control of territory. It is not a common nature of terrorists to establish and maintain physical control of a State's territory. As a strategy of insurgency, terrorism mostly makes use psychological influence to achieve their political objectives. As a strategy of insurgency, terrorism mostly makes use psychological influence to achieve their political objectives. Terrorism as a strategy of insurgency in contrast to all other strategies of insurgency thoroughly has no regard for internationally set rules of war engagement. In the case of guerrilla war and even conventional wars, these rules are often broken, and there are penalties for offenders. But in the case of terrorism, terrorists generally operate in the absence of rules by failing to recognise the difference between combatants and noncombatants. The entire population is viewed as a means to their end, and this is why terrorism unlike guerrilla, demonstrations, has no legal standing domestically in any country and internationally. And this is why terrorism has been defined as "an illegal form of warfare [14] of which war is fought on their own standards, capabilities, and no rules of engagement. Terrorists mode of operations have often taken the form off setting explosives in public places, kidnapping, killing of opponents, hijacking, hostage taking, barricading themselves in enclosed places to prevent access to the public. Take for example alQaeda's hijacking of two planes and their flying of the planes into the Twin-Towers (World Trade Centre) in the United States of America on September 11, 2001, or Boko Haram kidnapping of over 250 Chibuk girls from school [15].

\subsection{Counter Insurgency}

The term counter insurgency as indicated by the name refers to measures set in place to halt insurgency in whichever form it surfaces such as; coup, guerrilla, nonviolent resistance, revolution, terrorism etc. [16]The focus of counter insurgency is to prevent the change of regime or to reinstate the structure of authority. Counter insurgency also refers to a theory of war that may sometimes be used to describe an established set of methods that a State may use to counteract, defeat the advances of insurgents.

The term is traceable to the twentieth century, particularly ascribed to the President John F. Kennedy's administration; the administration was tackling how to deal with what they perceived as Soviet efforts to destabilize and undermine governments of the Third World countries and bring them under Soviet regime preceding decolonization. Counter insurgency is a combination of psychological, economic, military, paramilitary actions utilised by State government to counteract the advances of insurgents. The term became an international phenomenon as a result of the alQaeda attack on September 11, 2001. Following the attack, international and regional organisations have made counter insurgency a priority. 
In the process of countering insurgency, the host governments do work with foreign government and international organisations to mitigate the opposition and defend the legitimate government .It is a very tactical operation; it is proactive in nature and involves elements of a State's power. The operations involved attempt to realize unity of between the several units that forms the force, these may be; multinational organisations and intergovernmental organisations. Processes involved in counter insurgency are; planning; recruiting; financing, intelligence gathering, analysis of information; advice; training; organisational and technical assistance; infrastructure development; and information engagement.

For insurgency to be mitigated, the nature of the insurgency has to be taken into consideration. The factors propelling the actions are meant to be studied [17]. In essence this posits that for policy makers to adequately formulate and implement policies that would counteract insurgency, it is expedient that they have credible knowledge on factors that caused the uprising. In the words [18], an all-inclusive response to insurgency is a product of the root causes.

[16] adds that the system of administration is also a key factor to consider when planning counter insurgency plans; he explains that counter insurgency plans that prove effective in defending the authority of the government in an authoritarian state may prove to be ineffective when adopted to counter insurgents in a democratic regime.

\subsubsection{Approaches to Counterinsurgency}

Counter insurgency as indicated by the term refers certain set of responses threats of insurgency this requires a deep understanding of the threat matrix, which arises from knowledge of the relevant political, cultural, security, economic and social factors coupled with understanding the motivation, objectives and modus operandi of the insurgent groups [19]. Also pertinent to securing the support and the trust of the populace is to ensure the dissemination of quality governance aided through ensuring strict adherence to the rule of law, provision of basic social amenities to the people, political reforms, and economic reforms. Therefore, a good counter insurgency operation ought to be multidimensional [3].

\subsubsection{The Enemy-Centric Approach:}

This approach to counterinsurgency is aimed at defeating an identified enemy as it main objective, while considering other factors as secondary objectives. Simply put that the total amelioration of the security threat in all forms they appear while not paying much attention to nation building or support of the people is what constitute the enemy centric approach. Within this approach are variances such as soft power versus hard power, direct altercation versus indirect altercation, violent versus nonviolent, etc.

\subsubsection{The Population Centric Approach}

This approach is the direct opposite of the above approach to counter insurgency. This approach centers on the protection of citizens in other to win the support for the regime in the process of countering insurgency. This approach does not ignore the use of direct force, however it is not considered to be the primary means to curbing insurgency. [20] describes this approach as population first response to insurgency. This approach is more supported by scholars than the above approach; U.S counter insurgency style is patterned after is approach [3].

In the fight against insurgency, it is rarely seen for a single approach to be utilized, instead what we have is a mix of elements from both approaches at varying levels, the levels change over time depending on the decision of the regime.

\section{The Multinational Joint Task Force (MNJTF)}

The MNJTF that was formed to curb insurgency in the Lake Chad region was not the first of its kind. Prior to 2012, during the reign of General Sani Abacha there existed a task force of its kind to police the northeastern borders of Nigeria [21] the sole aim of the task force was to curb banditry and aid movement of people and properties. At inception, the force assumed a National front as only Nigeria was involved. However by 1998 , the force assumed a more multinational front with the involvement of Niger and Chad and it had the mandate of securing the borders in the Lake Chad region. At this time the headquarters of the force was located in Baba town of Borno State Nigeria. This case changed in 2012. In 2012, the expansion of the infamous group necessitated the equal expansion of the group's mandate to include counter insurgency with a major focus on Boko Haram. The multinational nature of the taskforce was even enlarged in 2012 to include elements not only form Nigeria and Niger but from Chad, Cameroon and Benin Republic. MNJTF was tasked to operate with other counter insurgency operations like the JTF Operation Restore Order and Operation Lafia Dole [22]. 


\subsection{Funding and Logistics of the MNJTF}

A large percentage of the funding of the operations of the MNJTF comes from the countries that make up the task force. However, significant amount also come from donor countries and institutions. At the 2016 Addis Ababa Donors' Conference, financial commitment to the Task Force recorded \$250 million. The Nigerian Government pledged a sum $\$ 100$ million, and as at 2016, had met \$30 million of her commitment. Also, the United Kingdom provided $\$ 3.5$ million to the outfit, while the European Union provided E50 million. Also to Benin, Chad and Niger, the regional Community of Sahel-Saharan States provided for the running of the Task Force a sum of $\$ 1.5$ million to assist with these countries financial burden. Despite the numerous contributions from external parties, the funding of the Task Force is heavily depended on the Member States of the MNJTF, and it should be noted that these member States due to the operations of insurgent groups are heavily weighing down on economic activities in the countries (Alufoge, 2020). The United States has also been involved in the fight against insurgency in the region, at the demand of the Nigerian government, USA deployed drones to survey Sambisa forest in search of the abducted Chibuk girls. Also, 12 US troops were deployed to Nigeria to train 650 combatants. In addition, equipment and financial assistance have been provided by US to help in the fight against insurgency, and such assistance is estimated to be 71 US dollars [19]. Through the European Union and African union partnership, EU provided a sum of 50 million euros to support the activities of MNJTF against Boko Haram at African Union Commission's donor Conference in 2016 (Alufoge, 2020). In assistance of the task force, France provided 10 transporters aircrafts for mobility, 200 armored vehicles, four Assault Rafale fighters, French Army helicopters stationed in Mali, general atomic mq-9 reaper unmanned aeriel vehicles, pledged to donate E130 millions to develop amenities, three lance roquette unitaire (LRU) systems, and some members of the Task Force received military training from French armies [19].

\subsection{Achievements of the Multinational Joint Task Force}

The MNJTF had its first major operation in 2016. Despite major challenges, the Task Force recorded major strides against the Boko Haram. Starting in the month of June of 2016, and ending in November of the same year, Gama Aiki (Complete the Job) was in [24]. The operation was held in Borno State and other parts of the LCBR, it entailed integrated military actions from the member States. The success of the Gama Aiki to liberate areas that were under the control of Boko Haram has been able to boost the morale of the Task Force.

In the 11th month of 2015, a strike by the MNJTF sector 2 was launched against Boko Haram. The success of the strike included the surrender of an estimate of 250 Boko Haram fighters. In 2015 the Cameroon faction of MNJTF was able to counteract a large number of Boko Haram fighters [25]. The MNJTF were also able to free hostages, recover weapons and clamp-down on some Boko Haram training camps.

Achievement of the Task Force is visible in the case that incidence of bombing have largely reduced, this is a result of tightening the flow of weapons, information and financial supply [26] Also, the effectiveness of the Task Force was echoed by the UNSG for Political Affairs, he stated "the UN commends the actions of the Lake Chad Basin countries to curb insurgency through the MNJTF [27].

The task force has been able to set free communities that were under the control of the infamous group, such communities include Gore Blangafe, Gore Mahamat, Kirta-Woulgo, Segui, Damboure and Chaugry, these liberated communities remain under the protection of the task force. Also the MNJTF has been able to weaken the capabilities of Boko Haram's ability to inflict sufferings on civilians, in a 2019 post by Premium times, reporting a statement by the field Commander Chikezie Ude, he reports that attacks on citizens previously at 2000 in 2015 dropped to 573 in 2018.

In addendum, members of the Task Force have been able to kill or lockup members of the insurgent group. In Cross Kauwa Lake Chad area, 52 Boko Haram fighters were killed in April 2019, 5 in Bormo state on the 31st of March 2019 etc. MNJTF has also been able to arrest Boko Haram fighters in Nigeria and Cameroon, and over 240 Boko Haram fighters surrendered to the MNJTF in 2016 [26].

\subsection{Challenges of the Multinational Joint Task Force \\ MNJTF is not a full prove plan against insurgency} in the LCR and it faces some challenges that impede its operations [28]. Zamfir (2015) is also of this opinion, he perceives the MNJTF to be faced mainly by logistical difficulties and absence of a true regional front from member States. This is echoed by [26] who point out the manner in which member States are only interested in fighting the insurgency to the extent at which it affects them and not how it affects other States. This can be attributed to be the 
reason the MNJTF was not quickly reactivated, as neighbouring States viewed the Insurgency to be a Nigerian problem. The neighouring States alone are not to blame, according to [25], the initial challenge to the MNJTF was caused by the Nigerian government, which were not willing to allow international intervention on Nigerian soil. [25] opines that the MNJTF was considered to be a form of threat to pride and sovereignty of the Nigerian State. Even after the reactivation of the Task Force, the division in the group is reflected in the structure of the group, with each country having a National headquarters and undertaking unilateral missions.

[19] states that there is rivalry in the region, neighouring countries are threatened by Nigeria as a result of her economy, population and natural resources. This fear makes the surrounding francophone countries to fear being overpowered by Nigeria. The rivalry between the francophone countries and Nigeria have been reflected in the operations of MNJTF, for instance, the Chad sector of the MNJTF deployed troops to Nigeria without a prior notice to the Nigerian division of the task Force. In the case of Niger and Nigeria, Nigerien soldiers referred to Nigerian soldiers as cowards, while the latter responded by calling the former serial looters [25]. For a regional response to insurgency, this was not a healthy start. This weak start spiraled into a series of clumsy and unorganized military actions by the Task Force. It should also be noted that whenever there was a victorious strike against Boko Haram, individual sectors do claim responsibility for the success of the mission instead of ascribing the success to the regional Task Force. It took several attacks by the insurgents to get the member States to cooperate.

A major challenge inhibiting the operations of the MNJTF is that the financial contributions from member States have been insufficient to curb the insurgent group's activities [26], this resulted in sourcing finances from external partners, notwithstanding the financial contributions from external partners, the contribution still didn't meet up to the estimated amount of US\$700 million. It is worthy of note to state that the economic down turn that member States are experiencing as at the time of observation have also made it difficult for them to meet up with their pledges [25]. The countries are also faced with the burden of providing for refugees and internally displaced persons. Hence these countries are financially strained. Also, the UN proposed to set a trust fund for the maintenance of the Task Force in other to mobilize the much needed logistical and financial support. However this has yet to be established and this remains a major challenge to the operations of the [26]

The regional military response is not only underfunded, but there is also the problem of inadequate technical-knowhow [30]. He discusses further that the MNJTF is not trained to handle unconventional warfare. Unlike conventional warfare in which the enemy is known and rules of engagement are followed, the fight against Boko Haram is unconventional; rules of engagement do not apply, also states that the problem of technical knowhow and under-funding as trickled down into lack of commitment on the parts of the soldiers who feel they are unequipped sitting ducks to be preyed upon by Boko Haram [30].

\section{Conclusion and Problem Solution}

Insurgency is major feature of the Lake Chad region and if not properly manage, will be a threat to the entire West Africa. The sole use of force to curb insurgency has been able to limit the activities of insurgents, but has not been able to entirely bring an end to the incessant menace, and this is because insurgency is a symptom having multidimensional causes; not just a product of religious extremism, but a combined product of factors like economic hardship worsened by the drying up of the Lake Chad that serves as source of livelihood for many; religious intolerance propagated through hate sermons by religious leaders, distrust in the government due to years of political malpractices by government officials etc.

The Task Force in their attempts to curb insurgency has also inflicted pain on noncombatants, which has fed into the rhetoric of the Boko Haram. The extra judicial execution of Mohammed Yusuf in custody made him a martyr and his death was a powerful tool to bring sympathizers together. In the same vein, citizens who have experienced the brutality of the MNJTF first hand are likely to believe the message of the insurgent group, which limits the effectiveness of the Task Force.

Even though there is relative stability and the attacks by the group has reduced, there should not be a recess in counter insurgency, this regional response should be reinforced and strengthened to prevent a resurgence of Boko Haram or another group from taking its place.

\section{References: \\ [1] Author, Title of the Paper, International Journal of Science and Technology, Vol.X, No.X, 200X, pp. XXX-XXX.}


[2] Author, Title of the Book, Publishing House, 200X.

[3] Clarke, S. and Lekalake, R., .Extremism in Africa: Public opinion from the Sahel, Lake Chad, and the Horn. Afrobarometer Policy Paper, 2016, Addis Ababa

[4] Hoffman, B. Inside Terrorism. New York: Columbia University Press, 2006.

[5] Akanni, N. K., Counter-Insurgency and Human Rights Violations in Nigeria. Journal of Law, Policy and Globalization, Volume 85, 2019, DOI: 10.7176/JLPG

[6] Albert, I. O., Rethinking the Functionality of the Multinational Joint Task Force in Managing the Boko Haram Crisis in the Lake Chad Basin. Africa Development, Volume XLII, No. 3, 2017, 119-135.

[7] Assanvo, W., Abatan, J., \& Sawadogo, W., West Africa Report: Assessing the Multinational Joint Task Force against Boko Haram, Institute for Security Studies, 2016

[8] Omolaye-Ajilaye, A., "Legal Framework for the Prevention of Terrorism in Nigeria", 2 NIJ Law Journal, 38, 2015.

[9] Ajayi, Y., What We Know About Boko Haram's New Leader, Abu Musab al-Barnawi. 137 Assessed on 7th August 2016 from http://www.vanguardngr.com/2016/08/knowbokoharams-new-leader-abu-musab-albarnawi/

[10] Marshall, C., \& Rossman, G. B. Designing Qualitative Research. Newbury Park, CA: Sage, 1989.

[11] Schatzman. L., \& Strauss. A., Field Research: Strategies For A Natural Sociology. Englewood Cliffs: Prentice-Hall, 1973. 149 pp.

[12] Fearon, J.D., and Laitin, D.D. Ethnicity, Insurgency, and Civil War. The American Political Science Review 97 (1), 2003, pp7590.

[13] Lyall, J., and Wilson, I. (2009) Rage Against the Machines: Explaining Outcomes in Counter insurgency Wars. ,'International Organisation. 63(1), 2009: 67-106

[14] O'Neill, B. E., Insurgency \& Terrorism: From Revolution to Apocalypse (2nd ed.). Washington D. C.: Potomac Books, Inc 2005.

[15] Taber, R. War of the Flea: The Classic Study of Guerilla Warfare. Washington D.C.: Potomac Books, Inc, 2002.

[16] Merari, A. Terrorism As A Strategy of Insurgency. In: Chaliand, G. and Blin, A. ed. The History of Terrorism: From Antiquity to Al
Qaeda. University of California Press: Berkely, 12-54, 2013.

[17] Dikki, M. E. Boko Haram In Northern Nigeria: A Maududian Legacy. A new journal of African studies, 13, 2, 2017, 91-115.

[18] Arreguin T. I,, The future of insurgencies and COIN Armed Forces and Insurgents in Modern Asia 2017, p212

[19] Crelinsten, R.. Counter-terrorism. Cambridge: Polity Publishers, 2009.

[20] Kundnani, A. A Decade Lost: Rethinking Radicalization and Extremism. New York: Oxford University Press.2015

[21] Dauda, H., The Role Of The Multinational Joint Task Force In Fighting Against Book Haram In Africa, 2017 (Published MSc Thesis). University Of Ghana, Legon.

[22] Williams, K., "The Other Side of the COIN: Counterinsurgency and Community Policing", 3 A Journal for Social Movement, 97.2011.

[23] Albert, I.O. and N.D. Danjibo,' 'Borno: Fitting the Designs of Political Elite' in Isumonah, A.V., ed., Participatory Democracy and Good Governance in Nigeria, Ibadan: Programme on Ethnic and Federal Studies, 2004.

[24] Musa, S.,, 'Baga: Multinational Joint Task Forces, BHTs and Host Community, Sahara Reporters, 7 May, http://saharareporters.com/2013/05/07/bagamul tinational-joint-task-forces-bhts-and-hostcommunity-lt-col-sagir-musa, accessed 4 February 2020.

[25] Azutoro, D. An Appraisal of the MNJTF in Curbing Insurgency in the Lake Chad Basin Region. (F. Alufoge, Interviewer) Researcher's field work, 2019.

[26] Dze-Ngwa, W., The Multinational Joint Task Force against Boko Haram: Rethinking Military Interventions. International Journal of Liberal Arts and Social Science, 6(7), 2018, pp 15-24.

[27] Usman A. T., and Adejoh, S., Military Alliance and Counter-Terrorism in SubSaharan Africa: The Multi-National Joint Task Force in Perspective. Covenant University Journal of Politics \& Internationall Affair, 5(2) 2017, pp1-12

[28] Adeola, G. L.. An Appraisal of the MNJTF in Curbing Insurgency in the Lake Chad Basin Region, 2019, (F. Alufoge, Interviewer) Researcher's field work.

[29] Feltman, J. Peace and security in Africa: being a report on Boko Haram presented to 
the 7748th meeting of the United Nations Security Council, 2016.

[30] Onoh, K., An Appraisal of the MNJTF in Curbing Insurgency in the Lake Chad Basin Region. 2019, (F. Alufoge, Interviewer) Researcher's field work.

\section{Contribution of individual authors to} the creation of a scientific article (ghostwriting policy)

Olufunso Kehinde Alufoge carried out this research Data curation, investigation, and writing original draft.

Validation and reliability of the research instrument and data was ensured by Dr. Moses Meturama Durui who also supervised the research enavour and writing editing and reviewing the paper.

\section{Sources of funding for research presented in a scientific article or scientific article itself}

Publication of this research was sponsored by Covenant University Ota Ogun State Nigeria
Creative Commons Attribution License 4.0 (Attribution 4.0 International, CC BY 4.0)

This article is published under the terms of the Creative Commons Attribution License 4.0

https://creativecommons.org/licenses/by/4.0/deed.en US 